\title{
Halostagnicola kamekurae sp. nov., an extremely halophilic archaeon from solar salt
}

Correspondence

Shuhei Nagaoka wildspeed24@gmail.com

\author{
Shuhei Nagaoka, ${ }^{1}$ Hiroaki Minegishi, ${ }^{2}$ Akinobu Echigo ${ }^{2}$ and Ron Usami ${ }^{2}$ \\ 'Department of Biological Applied Chemistry, Graduate School of Engineering, Toyo University, \\ 2100 Kujirai, Kawagoe, Saitama 350-8585, Japan \\ ${ }^{2}$ Bio-Nano Electronics Research Centre, Toyo University, 2100 Kujirai, Kawagoe, Saitama 350- \\ 8585, Japan
}

\begin{abstract}
A novel extremely halophilic archaeon, strain $194-10^{\top}$, was isolated from a solar salt sample imported into Japan from the Philippines. Strain $194-10^{\top}$ was pleomorphic, neutrophilic and mesophilic and required at least $10 \%(\mathrm{w} / \mathrm{v}) \mathrm{NaCl}$ but no $\mathrm{MgSO}_{4} .7 \mathrm{H}_{2} \mathrm{O}$ for growth; it exhibited optimal growth at $15 \%(\mathrm{w} / \mathrm{v}) \mathrm{NaCl}$ and $60 \mathrm{mM} \mathrm{MgSO}_{4} .7 \mathrm{H}_{2} \mathrm{O}$. Strain $194-10^{\top}$ grew at $20-$ $45{ }^{\circ} \mathrm{C}$ (optimum, $30{ }^{\circ} \mathrm{C}$ ) and $\mathrm{pH}$ 6.0-9.0 (optimum, pH 6.5-7.0). The $\mathrm{G}+\mathrm{C}$ content of its DNA was $59.8 \mathrm{~mol} \%$. 16S rRNA gene sequence analysis revealed closest proximity to Halostagnicola larsenii $\mathrm{XH}-48^{\top}$ (98.5\% similarity), the sole representative of the genus Halostagnicola. Polar lipid analysis revealed that strain $194-10^{\top}$ contained phosphatidylglycerol and phosphatidylglycerol phosphate methyl ester (the latter derived from both $\mathrm{C}_{20} \mathrm{C}_{20}$ and $\mathrm{C}_{20} \mathrm{C}_{25}$ archaeol) and several unidentified glycolipids. The results of DNA-DNA hybridization (20.7\% relatedness between $\mathrm{Hst}$. larsenii JCM $13463^{\top}$ and strain $194-10^{\top}$ ) and physiological and biochemical characteristics allowed differentiation of strain $194-10^{\top}$ from Hst. larsenii $\mathrm{XH}-48^{\top}$. Therefore, strain $194-10^{\top}$ represents a novel species of the genus Halostagnicola, for which the name Halostagnicola kamekurae sp. nov. is proposed, with the type strain $194-10^{\top}\left(=\mathrm{DSM} 22427^{\top}=\mathrm{JCM} 16110^{\top}\right.$ $=$ CECT $7536^{\top}$ ).
\end{abstract}

The haloarchaea constitute a large group of extremely halophilic, aerobic archaea that are placed in the order Halobacteriales, family Halobacteriaceae (Grant et al., 2001). At the time of writing (December 2009), the family Halobacteriaceae contains 27 genera comprising 104 species (Savage et al., 2008; Oren et al., 2009; http://www.the-icsp. org/taxa/halobacterlist.htm; http://www.bacterio.cict.fr/) that display a wide variety of physiological characteristics, including ranges of salinity, temperature and $\mathrm{pH}$ for growth. The genus Halostagnicola, belonging to the family Halobacteriaceae, currently contains only one species and one strain, Halostagnicola larsenii $\mathrm{XH}-48^{\mathrm{T}}$, isolated from sediment of Lake Xilinhot, a saline lake in Inner Mongolia, China (Castillo et al., 2006). The strain is pleomorphic, neutrophilic and requires at least $15 \%(\mathrm{w} / \mathrm{v}) \mathrm{NaCl}$. The highest 16S rRNA gene sequence similarities are obtained with Natrialba aegyptiaca $40^{\mathrm{T}}$ and Natrialba asiatica $172 \mathrm{P}^{\mathrm{T}}$. Polar lipids are phosphatidylglycerol and phos-

Abbreviation: PGP-Me, phosphatidylglycerolphosphate methyl ester.

The GenBank/EMBL/DDBJ accession number for the 16S rRNA gene sequence of strain $194-10^{\top}$ is AB489220.

Thin-layer chromatograms of polar lipids of strain $194-10^{\top}$ and related haloarchaea and a $16 S$ rRNA gene sequence-based maximumlikelihood tree are available as supplementary figures with the online version of this paper. phatidylglycerol phosphate methyl ester, the latter derived from both $\mathrm{C}_{20} \mathrm{C}_{20}$ and $\mathrm{C}_{20} \mathrm{C}_{25}$ archaeol, and two unidentified glycolipids. We isolated a strain closely related to $H s t$. larsenii $\mathrm{XH}-48^{\mathrm{T}}$ from an imported solar salt sample. In this report, we characterize strain $194-10^{\mathrm{T}}$ and describe its identification. Hst. larsenii $\mathrm{XH}-48^{\mathrm{T}}$ was obtained from the Japan Collection of Microorganisms as JCM $13463^{\mathrm{T}}$ and used as a reference strain.

Strain $194-10^{\mathrm{T}}$ was isolated from a sample of solar salt imported into Japan from the Philippines. The solar salt sample has been on the market from a Japanese firm as 'Mangrove' (http://www.77ochiai.com/page/syouhin06783gift.htm) as a $200 \mathrm{~g}$ package. To $1 \mathrm{~g}$ of the salt sample, $4 \mathrm{ml}$ sterile distilled water was added gradually, and three drops of the solution were spread on agar plates of JCM medium no. 168 containing the following $\left(1^{-1}\right): 5.0$ geast extract, $5.0 \mathrm{~g}$ Casamino acids, $1.0 \mathrm{~g}$ sodium glutamate, $2.0 \mathrm{~g} \mathrm{KCl}, 3.0 \mathrm{~g}$ sodium citrate, $20.0 \mathrm{~g} \mathrm{MgSO}_{4} .7 \mathrm{H}_{2} \mathrm{O}$, $200.0 \mathrm{~g} \mathrm{NaCl}, \quad 36.0 \mathrm{mg} \quad \mathrm{FeCl}_{2} \cdot 4 \mathrm{H}_{2} \mathrm{O}$ and $0.36 \mathrm{mg}$ $\mathrm{MnCl}_{2} .4 \mathrm{H}_{2} \mathrm{O}$. The medium was adjusted to $\mathrm{pH} 7.0$ with $40 \%(\mathrm{w} / \mathrm{v}) \mathrm{KOH}$. About 30 colonies appeared on an agar plate, and six colonies of different colours were selected and purified by repeated serial dilution; partial $16 \mathrm{~S}$ rRNA gene sequences were then determined. Sequences of five of the strains were closely related (more than 99.2\% 
similarity) to those of haloarchaea of the genera Haloarcula and Halorubrum. A pink colony designated strain $194-10^{\mathrm{T}}$ showed $98.5 \%$ partial $16 \mathrm{~S}$ rRNA gene sequence similarity to Hst. larsenii $\mathrm{XH}-48^{\mathrm{T}}$. Colony morphology was observed on agar medium under optimal growth conditions after incubation at $37{ }^{\circ} \mathrm{C}$. Gram staining was performed according to Dussault (1955). Cell morphology and motility were examined using phase-contrast microscopy (Zeiss Axiovert 135). Colonies of strain $194-10^{\mathrm{T}}$ on agar plates were circular, smooth, opaque and white and turned pink gradually after $2-3$ weeks. The cells were motile and pleomorphic, exhibiting rod-shaped or teardrop-shaped morphology, and approximately $0.8-1.0 \times 2.0-2.5 \mu \mathrm{m}$. Cells lysed in distilled water. There were no gas vesicles inside the cells.

Growth ranges and optima for $\mathrm{NaCl}$ and $\mathrm{Mg}^{2+}$ were determined by using the growth medium containing various concentrations of $\mathrm{NaCl}(0-30 \%, \mathrm{w} / \mathrm{v})$ and $\mathrm{MgSO}_{4} \cdot 7 \mathrm{H}_{2} \mathrm{O}(0-100 \mathrm{mM})$, at intervals of $5 \%(\mathrm{w} / \mathrm{v})$ and $10 \mathrm{mM}$, respectively. The $\mathrm{pH}$ range for growth was assayed in liquid medium at $\mathrm{pH} 6.0-10.0$ at intervals of $0.5 \mathrm{pH}$ units. The temperature range for growth of strain 194-10 ${ }^{\mathrm{T}}$ was determined at $4,10,15,20,25,30,35,37,40,45$ and $50{ }^{\circ} \mathrm{C}$ at pH 7.0 with optimal $\mathrm{NaCl}$ and $\mathrm{Mg}^{2+}$ concentrations. Strain $194-10^{\mathrm{T}}$ was capable of growing over a wide range of $\mathrm{NaCl}$ concentration $[10-30 \%(\mathrm{w} / \mathrm{v})] \cdot \mathrm{Mg}^{2+}$ was not required for growth. The strain grew optimally in the presence of $15 \%(\mathrm{w} / \mathrm{v}) \mathrm{NaCl}$ and $60 \mathrm{mM} \mathrm{MgSO}_{4} \cdot 7 \mathrm{H}_{2} \mathrm{O}$. Strain $194-10^{\mathrm{T}}$ grew at $20-45{ }^{\circ} \mathrm{C}$ (optimum, $30{ }^{\circ} \mathrm{C}$ ) and pH 6.0-9.0 (optimum, pH 6.5-7.0).

Total DNA was extracted by the method of Cline et al. (1989). The DNA G + C content was determined by the HPLC method of Tamaoka (1994). The DNA G+C content of strain $194-10^{\mathrm{T}}$ was $59.8 \mathrm{~mol} \%$, which was similar to that reported for Hst. larsenii $\mathrm{XH}-48^{\mathrm{T}}$ (61.0 mol\%; Castillo et al. 2006). The 16S rRNA gene of strain $194-10^{\mathrm{T}}$ was amplified by PCR with the forward and reverse primers $5^{\prime}$-ATTCCGGTTGATCCTGCCGG and $5^{\prime}$ AGGAGGTGATCCAGCCGCAG, as described previously (Fukushima et al., 2007). Amplification products were cloned into the pCR2.1 $\mathrm{T}$ vector (Invitrogen) and five clones were sequenced using the Big Dye sequencing kit version 3.1 (Applied Biosystems) using an ABI 310 DNA sequencer. 16S rRNA gene sequences retrieved from the
DDBJ (Miyazaki et al., 2003) were aligned. A phylogenetic tree was reconstructed by the neighbour-joining method (Saitou \& Nei, 1987) and was evaluated by bootstrap sampling with 1000 replicates (Felsenstein, 1985). Maximum-likelihood analysis was performed with RAxML 7.0.4 using the GTR $+\Gamma$ model (Stamatakis et al., 2005), and support for the maximum-likelihood tree was obtained by bootstrapping (1000 replicates) using CONSENSE in PHYLIP. The five 16S rRNA gene clones from strain $194-10^{\mathrm{T}}$ gave exactly the same sequence, which was the closest to that of Hst. larsenii JCM $13463^{\mathrm{T}}$ (DDBJ accession no. AB301489), with $98.5 \%$ similarity; similarities to sequences of other species of the Halobacteriaceae with validly published names were less than $95.0 \%$, the highest being $94.9 \%$ with Nab. hulunbeirensis AS $1.1986^{\mathrm{T}}$ and $94.6 \%$ with Nab. aegyptiaca $40^{\mathrm{T}}$. The sequence represented by DDBJ accession number AB301489 (1433 nt) was deposited by one of the authors of this paper (H. M.) in April 2007; this sequence was the same as that represented by AM117571 (1372 nt), deposited by A. Castillo, except for five nucleotides at positions 659-663 of AM117571. The neighbour-joining (Fig. 1) and maximumlikelihood (Supplementary Fig. S1, available in IJSEM Online) trees also supported the conclusion that the strain $194-10^{\mathrm{T}}$ was most closely related to Hst. larsenii $\mathrm{XH}-48^{\mathrm{T}}$. DNA-DNA hybridization was performed by the fluorometric method of Ezaki et al. (1989); the relatedness between strain $194-10^{\mathrm{T}}$ and Hst. larsenii JCM $13463^{\mathrm{T}}$ was $20.7 \%(n=3)$. This value was well below the threshold value of $70 \%$ generally accepted for the definition of distinct species (Wayne et al., 1987; Stackebrandt \& Ebers, 2006).

Polar lipids were extracted with chloroform/methanol as described previously (Kamekura, 1993). TLC was performed using HPTLC silica gel 60 plates $(20 \times 10 \mathrm{~cm}$; Merck) with the solvent system chloroform/methanol/ acetic acid/water $(85: 22.5: 10: 4$, by vol.). Phospholipids were detected as blue spots by spraying with DittmerLester reagent (Minnikin et al., 1984). Glycolipids were detected as purple spots by spraying with $0.5 \%(\mathrm{w} / \mathrm{v}) \alpha$ naphthol in methanol/water $(1: 1)$ and then with sulfuric acid/ethanol $(1: 1)$, followed by brief heating at $160{ }^{\circ} \mathrm{C}$. Polar lipids were detected as brown spots after prolonged heating. TLC of the polar lipids (Supplementary Fig. S2) suggested that strain $194-10^{T}$ contained phosphatidylgly-

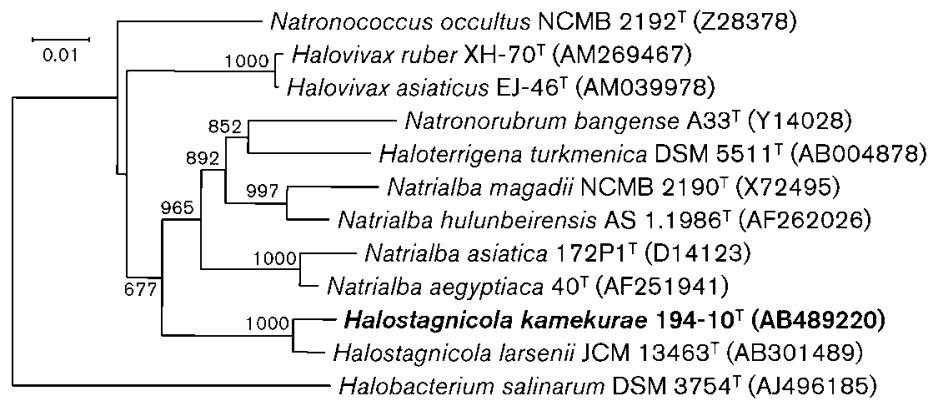

Fig. 1. Phylogenetic tree reconstructed by the neighbour-joining method derived from $16 \mathrm{~S}$ rRNA gene sequences showing the position of strain $194-10^{\top}$ among haloarchaea. Bootstrap values $>600$ (from 1000 replicates) are shown. Bar, $1 \%$ sequence divergence. 
cerol and phosphatidylglycerolphosphate methyl ester (PGP-Me) derived from both $\mathrm{C}_{20} \mathrm{C}_{20}$ and $\mathrm{C}_{20} \mathrm{C}_{25}$ archaeol, as shown by the two spots for PGP-Me. Phosphatidylglycerol sulfate was not detected. Several unidentified glycolipid spots were detected. Two major spots detected above PGP-Me were not observed in Hst. larsenii JCM $13463^{\mathrm{T}}$ in this study or by Castillo et al. (2006). Minor glycolipids similar to those of Hst. larsenii JCM $13463^{\mathrm{T}}$ were also detected.

Phenotypic tests were performed according to the proposed minimal standards for the description of new taxa in the order Halobacteriales (Oren et al., 1997). All tests were done in our laboratory on both strain $194-10^{\mathrm{T}}$ and Hst. larsenii JCM $13463^{\mathrm{T}}$. Tests for catalase and oxidase activities and for the hydrolysis of starch, gelatin, casein and Tween 80 were performed as described by Gonzalez et al. (1978). Reduction of nitrate was detected by using the sulfanilic acid and $\alpha$-naphthylamine reagent (Smibert \& Krieg, 1981). $\mathrm{H}_{2} \mathrm{~S}$ formation was determined by monitoring the production of a black sulfide precipitate in JCM medium no. 168 containing $0.5 \%(\mathrm{w} / \mathrm{v})$ sodium thiosulfate. Indole production from tryptophan and the utilization of sugars and organic acids were assessed as described by Oren et al. (1997). Strain $194-10^{\mathrm{T}}$ was oxidase- and catalase-negative. Nitrate reduction and indole production from tryptophan were positive. Tween 80 was hydrolysed, but starch, gelatin and casein were not hydrolysed. Strain $194-10^{\mathrm{T}}$ was urease-positive. Other results are included in the species description. Antibiotic sensitivity tests were performed by spreading a cell suspension on culture plates and applying discs impregnated with the following antibiotics (Becton Dickinson; amounts in $\mathrm{mg}$ unless indicated): ampicillin (10), bacitracin (10 U), chloramphenicol (30), erythromycin (15), gentamicin (120), kanamycin (30), nalidixic acid (30), neomycin (30), novobiocin (30), penicillin $\mathrm{G}$ (10 U), rifampicin (5), streptomycin (300), tetracycline (30) and vancomycin (30). Discs containing anisomycin $(50 \mathrm{mg})$ and pravastatin $(50 \mathrm{mg}$ ) were prepared in our laboratory and applied in the same way. The formation of acid from sugars and organic acids was assessed in a modified JCM medium no. 168 (Casamino acids, sodium glutamate and sodium citrate were omitted) with $0.5 \mathrm{~g}$ yeast extract $1^{-1}$, supplemented with $1 \%(\mathrm{w} / \mathrm{v})$ test substrate. After incubation for 2 weeks, acid formation was determined by using bromcresol green $\mathrm{pH}$ test paper. The results are included in the species description and differences between strain $194-10^{\mathrm{T}}$ and Hst. larsenii JCM $13463^{\mathrm{T}}$ are highlighted in Table 1. There were no discrepancies in phenotypic test results for Hst. larsenii JCM $13463^{\mathrm{T}}$ between those reported by Castillo et al. (2006) and those determined in our laboratory, showing that the differences between strain $194-10^{\mathrm{T}}$ and Hst. larsenii JCM $13463^{\mathrm{T}}$ highlighted in Table 1 are reliable.

The phylogenetic and phenotypic characteristics indicated strongly that strain $194-10^{\mathrm{T}}$ represents a novel species of the genus Halostagnicola, for which the name Halostagnicola kamekurae sp. nov. is proposed.
Table 1. Characteristics that distinguish strain $194-10^{\top}$ from Hst. larsenii JCM $13463^{\top}$

Data for Hst. larsenii JCM $13463^{\mathrm{T}}$ were taken from Castillo et al. (2006) and this study.

\begin{tabular}{|c|c|c|}
\hline Characteristic & $194-10^{\mathrm{T}}$ & $\begin{array}{c}\text { Hst. larsenii JCM } \\
13463^{\mathrm{T}}\end{array}$ \\
\hline Cell size $(\mu \mathrm{m})$ & $0.8-1.0 \times 2.0-2.5$ & $0.5-1.0 \times 1.0-3.0$ \\
\hline $\mathrm{NaCl}$ optimum $(\%, w / v)$ & 15 & 20 \\
\hline $\mathrm{NaCl}$ range $(\%, \mathrm{w} / \mathrm{v})$ & $10-30$ & $15-30$ \\
\hline pH optimum & $6.5-7.0$ & $7.0-8.0$ \\
\hline $\begin{array}{l}\text { Temperature optimum } \\
\left({ }^{\circ} \mathrm{C}\right)\end{array}$ & 30 & 37 \\
\hline Indole formation & + & - \\
\hline$\beta$-Galactosidase & - & + \\
\hline \multicolumn{3}{|l|}{ Hydrolysis of: } \\
\hline Starch & - & + \\
\hline Tween 80 & + & - \\
\hline \multicolumn{3}{|l|}{ Assimilation of: } \\
\hline Cellobiose & + & $+^{*}$ \\
\hline D-Fructose & - & + \\
\hline Maltose & - & + \\
\hline D-Mannitol & - & $+^{*}$ \\
\hline D-Mannose & + & $+^{*}$ \\
\hline Raffinose & + & - \\
\hline Ribose & - & + \\
\hline D-Xylose & - & + \\
\hline Citrate & - & $+^{*}$ \\
\hline Malate & + & - \\
\hline \multicolumn{3}{|l|}{ Acid production from: } \\
\hline L-Arabinose & + & - \\
\hline Mannose & + & - \\
\hline Sucrose & - & + \\
\hline \multicolumn{3}{|l|}{ Sensitivity to: } \\
\hline Anisomysin (50 mg) & + & $+^{*}$ \\
\hline Kanamycin (30 mg) & - & $-^{\star}$ \\
\hline Pravastatin (50 mg) & + & $+^{*}$ \\
\hline Rifampicin (5 mg) & + & - \\
\hline Vancomycin (30 mg) & - & $-^{\star}$ \\
\hline Pigmentation & White $\dagger$ & Pink \\
\hline $\begin{array}{l}\text { DNA G }+\mathrm{C} \text { content } \\
(\mathrm{mol} \%)\end{array}$ & 59.8 & 61.0 \\
\hline
\end{tabular}

${ }^{\star}$ Determined in this study (not reported by Castillo et al., 2006). †Colonies gradually turn pink over 2-3 weeks.

\section{Description of Halostagnicola kamekurae sp. nov.}

Halostagnicola kamekurae (ka.me.ku'rae. N.L. gen. n. kamekurae of Kamekura, named after the Japanese microbiologist Masahiro Kamekura, who contributed to the study of haloarchaea).

Gram-negative. Cells are motile and pleomorphic, rod- or teardrop-shaped. Cells are approximately $0.8-1.0 \times 2.0$ $2.5 \mu \mathrm{m}$. Colonies on agar medium are circular, white and $2-3 \mathrm{~mm}$ in diameter, and gradually turn pink upon incubation for 2-3 weeks. Growth occurs at $10-30 \%$ (w/ 
v) $\mathrm{NaCl}$ (optimum, $15 \%$, w/v). Cells lyse in water. $\mathrm{Mg}^{2+}$ is not required for growth (optimal $\mathrm{MgSO}_{4} \cdot 7 \mathrm{H}_{2} \mathrm{O}$ concentration is $60 \mathrm{mM}$ ). Grows at $20-45{ }^{\circ} \mathrm{C}$ (optimum, $30{ }^{\circ} \mathrm{C}$ ) and at $\mathrm{pH}$ 6.0-9.0 (optimum, $\mathrm{pH}$ 6.5-7.0). $\mathrm{H}_{2} \mathrm{~S}$ is not produced from sodium sulfite. Indole is produced from tryptophan. Nitrate is reduced to nitrite, but nitrite is not reduced further and no gas is formed. Anaerobic growth does not occur with DMSO, nitrate or arginine. Oxygen is used as the terminal electron acceptor. Tests for oxidase and catalase activities are negative. Tween 80 is hydrolysed. Casein, starch and gelatin are not hydrolysed. Acid is produced from L-arabinose and mannose. Arginine dihydrolase, lysine decarboxylase and ornithine decarboxylase are not produced. Tests for urease and phosphatase activities are positive, while $\beta$-galactosidase activity tests negative. The following substrates are utilized for growth: L-arabinose, D-galactose, D-glucose, glycerol, lactose, maltose, D-mannose, ribitol, raffinose, trehalose, acetate, glutamate, malate and propionate. No growth occurs on cellobiose, D-fructose, D-mannitol, ribose, D-sorbitol, sucrose, D-xylose, starch, citrate, fumarate or succinate. Sensitive to ( $\mathrm{mg}$ per disc unless indicated) anisomycin (50), bacitracin (10 U), novobiocin (30) and rifampicin (5) and resistant to ampicillin (10), chloramphenicol (30), erythromycin (15), gentamicin (120), kanamycin (30), nalidixic acid (30), neomycin (30), penicillin $\mathrm{G}(10 \mathrm{U})$, pravastatin (50), streptomycin (300), tetracycline (30) and vancomycin (30). Polar lipids are phosphatidylglycerol, phosphatidylglycerol phosphate methyl ester, two major unknown glycolipids and several unknown glycolipids. The DNA G + C content of the type strain is $59.8 \mathrm{~mol} \%$ (HPLC).

The type strain is strain $194-10^{\mathrm{T}}\left(=\mathrm{DSM} 22427^{\mathrm{T}}=\mathrm{JCM}\right.$ $16110^{\mathrm{T}}=$ CECT $7536^{\mathrm{T}}$ ), isolated from solar salt imported into Japan from the Philippines.

\section{References}

Castillo, A. M., Gutierrez, M. C., Kamekura, M., Xue, Y., Ma, Y., Cowan, D. A., Jones, B. E., Grant, W. D. \& Ventosa, A. (2006). Halostagnicola larsenii gen. nov., sp. nov., an extremely halophilic archaeon from a saline lake in Inner Mongolia, China. Int J Syst Evol Microbiol 56, 1519-1524.

Cline, S. W., Schalkwyk, L. C. \& Doolittle, W. F. (1989). Transformation of the archaebacterium Halobacterium volcanii with genomic DNA. J Bacteriol 171, 4987-4991.

Dussault, H. P. (1955). An improved technique for staining red halophilic bacteria. J Bacteriol 70, 484-485.

Ezaki, T., Hashimoto, Y. \& Yabuuchi, E. (1989). Fluorometric deoxyribonucleic acid-deoxyribonucleic acid hybridization in microdilution wells as an alternative to membrane filter hybridization in which radioisotopes are used to determine genetic relatedness among bacterial strains. Int J Syst Bacteriol 39, 224-229.

Felsenstein, J. (1985). Confidence limits on phylogenies: an approach using the bootstrap. Evolution 39, 783-791.

Fukushima, T., Usami, R. \& Kamekura, M. (2007). A traditional Japanese-style salt field is a niche for haloarchaeal strains that can survive in $0.5 \%$ salt solution. Saline Syst 3, 2 .

Gonzalez, C., Gutierrez, C. \& Ramírez, C. (1978). Halobacterium vallismortis sp. nov. An amylolytic and carbohydrate-metabolizing, extremely halophilic bacterium. Can J Microbiol 24, 710-715.

Grant, W. D., Kamekura, M., McGenity, T. J. \& Ventosa, A. (2001). Order I. Halobacteriales Grant and Larsen 1989b, 495 VP (effective publication: Grant and Larsen 1989a, 2216). In Bergey's Manual of Systematic Bacteriology, 2nd edn, vol. 1, pp. 294-299. Edited by D. R. Boone, R. W. Castenholz \& G. M. Garrity. New York: Springer.

Kamekura, M. (1993). Lipids of extreme halophiles. In The Biology of Halophilic Bacteria, pp. 135-161. Edited by R. H. Vreeland \& L. I. Hochstein. Boca Raton, FL: CRC Press.

Minnikin, D. E., O'Donnell, A. G., Goodfellow, M., Alderson, G., Athalye, M., Schaal, A. \& Parlett, J. H. (1984). An integrated procedure for the extraction of bacterial isoprenoid quinones and polar lipids. J Microbiol Methods 2, 233-241.

Miyazaki, S., Sugawara, H., Gojobori, T. \& Tateno, Y. (2003). DNA Data Bank of Japan (DDBJ) in XML. Nucleic Acids Res 31, 13-16.

Oren, A., Ventosa, A. \& Grant, W. D. (1997). Proposed minimal standards for description of new taxa in the order Halobacteriales. Int J Syst Bacteriol 47, 233-238.

Oren, A., Arahal, D. R. \& Ventosa, A. (2009). Emended descriptions of genera of the family Halobacteriaceae. Int J Syst Evol Microbiol 59, 637-642.

Saitou, N. \& Nei, M. (1987). The neighbor-joining method: a new method for reconstructing phylogenetic trees. Mol Biol Evol 4, 406425.

Savage, K. N., Krumholz, L. R., Oren, A. \& Elshahed, M. S. (2008). Halosarcina pallida gen. nov., sp. nov., a halophilic archaeon from a low-salt, sulfide-rich spring. Int J Syst Evol Microbiol 58, 856-860.

Smibert, R. M. \& Krieg, N. R. (1981). General characterization. In Manual of Methods for General Microbiology, pp. 409-443. Edited by P. Gerhardt, R. G. E. Murray, R. N. Costilow, E. W. Nester, W. A. Wood, N. R. Krieg \& G. B. Phillips. Washington, DC: American Society for Microbiology.

Stackebrandt, E. \& Ebers, J. (2006). Taxonomic parameters revisited: tarnished gold standards. Microbiol Today 33, 152-155.

Stamatakis, A., Ludwig, T. \& Meier, H. (2005). RAxML-III: a fast program for maximum likelihood-based inference of large phylogenetic trees. Bioinformatics 21, 456-463.

Tamaoka, J. (1994). Determination of DNA base composition. In Chemical Methods in Prokaryotic Systematics, pp. 463-470. Edited by M. Goodfellow \& A. G. O’Donnell. Chichester: Wiley.

Wayne, L. G., Brenner, D. J., Colwell, R. R., Grimont, P. A. D., Kandler, O., Krichevsky, M. I., Moore, L. H., Moore, W. E. C., Murray, R. G. E. \& other authors (1987). International Committee on Systematic Bacteriology. Report of the ad hoc committee on reconciliation of approaches to bacterial systematics. Int J Syst Bacteriol 37, 463-464. 